University of Pittsburgh Graduate School of Library and Information Sciences in September as professor of library science.

ALFRED SvENSON has been named chairman of the sciences libraries at the Catholic University of America, Washington, D.C.

John T. Thomas has taken up duties as acting head, reference department, F. D. Bluford library, North Carolina Agricultural and Technical State University, Greensboro.

EveretT M. Wallace is now systems librarian at the University of California, Riverside, library.

Peter Waters has accepted appointment to the position of restoration officer in the Library of Congress, Washington, D.C.

Dr. Joseph N. WhitTen has joined the faculty of the Graduate Library School, C. W. Post Center, Long Island University, Brookville, New York, as a professor of library science.

Mrs. Joy J. Woonson is in charge of the chemistry-physics library in the Kent State University libraries system, Kent, Ohio.

\section{Classified Advertising}

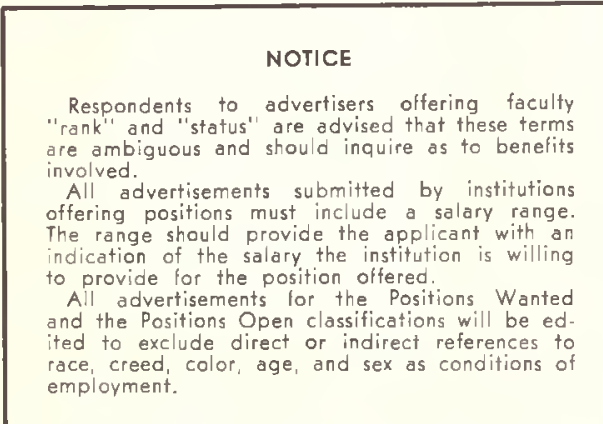

Classified advertising orders and copy, and cancellations, should be addressed to the Advertising Department, 50 East Huron Street. Chicago 606II, and should reach that office before the second of the month preceding publi. cation of issue desired. Copy received after that time may be held for the next issue.

Rate for classified advertising is $\$ 1.25$ per printed line. No additional charge is made for nonmember advertising.

\section{FOR SALE}

SPECIALISTS-THAT'S WHAT WE ARE. We sell all books published by University \& College Presses exclusively. Large stocks on hand. Billing according to specifica. tions, rapid shipments and follow-ups, $10 \%$ discount Send orders to University Press Book Service, 3025 th Avenue, New York, N.Y. 1000I, (212) 564-2049.

BOOKS OF ALL the University \& College Presses can be bought from one reliable source. We are the only jobber devoted exclusively to this lield. A $10 \%$ discount. rapid service, and thorough follow-ups. Send orders to University Press Book Service, 3025 th Avenue, New York, N.Y. $10001,(212)$ 564-2049.
IIBRARIANS: Did you know that there is one place where you can purchase all your University \& College Press books at a straight $10 \%$ discount? Large stock on hand. We are devoted exclusively to University Press titles. Send us your orders and watch a specialist per. form. University Press Book Service, 302 th Avenue, New York, N.Y, 10001 , (212) 564.2049

\section{WANTED}

COLOR PLATE BOOKS, Botanical, sporting, natural his tory, atlases, ornithology, costumes, views, landscapes. etc. Especially wanted Audubon, Catesby, Gould, Hud son River portfolio. Ackermann Publications, florals, etc. We will consider incomplete books \& volumes outwardly in bad condition-the plates being of main importance. Also Black and White illustrated books such as Piranesi. Bartlett. Allom, etc. J. N. Bartfield Books, Inc., 45 West 57 th Street, New York, N.Y. 10019.

\section{POSITIONS WANTED}

JUNE 1971 GRADUATE (MSLS) seeks position in an academic librapy with emphasis on Black Studies. Experience includes I year as student assistant to Alro-American bibliographer. BA in French. Available lor interview in June. Reply to Box 805, 50 East Huron Street, Chicago, Illinois 606 I.

LIBRARIAN/ANALYST/PROGRAMMER, with 4 years' experience in acquisitions and serials, desires responsible position in medium to large academic library. MSLS with background including systems design, familiarity with computers, and working knowledge of $\mathrm{COBOL}$ with computers, and working 5601 Chamberlain Drive, New Orleans, La. 70122.

\section{POSITIONS OPEN}

\section{Administration}

APPLICATION IS INVITED FOR THE POSITION OF REF. ERENCE SERVICE HEAD. Duties include coordination and supervision of the general and special reference and informational services in the main library. Active participation in reference work is required. The library has over 700,000 volumes and is growing rapidly. MLS required: second master's degree in a subject area is also desirable. Candidate should have five years' general aca. demic library reference experience and demonstrated supervisory and organizational ability. Excellent fringe benefit program. Salary range begins at \$11,500 for twelve months. Apply to Hans Engelke, Acting Head of Libraries, Western Michigan University, Kalamazoo, Mich. 49001 .

Technical Services

HEAD OF TECHNICAL SERVICES. Attractive opportunity or energetic innovative librarian. Responsible for developing, administering, and integrating the ordering, cataloging, and processing of library materials. Qualifications include experience, ambition, and imag ination. MLS required. Starting salary to $\$ 15,000$. Send resume to Jasper $G$. Schad Director of Libraries. Wichita State University, Wichita, Kansas 67208.

\section{Cataloging}

HEAD OF CATAloging, University of Denver. Position open immediałely. Supervise monographic cataloging department (4 professional and 26 clerks). MLS and appropriate experience required. Salary up to $\$ 12,000$ Faculty status: TIAA; liberal benefits. Interviews may be arranged at ALA Convention, Dallas. Write: David Shavit, Assistant Director for Technical Services, Denver, Colorado 80210. 


\section{SUBJECT SPECIALISTS}

PHYSICAL SCIENCE LIBRARIAN. Simon Fraser University requires a physical science librarian to work in the Sciences Division of the Library. Position involves col. lection development assistance to students and faculty in the use of the library, reference service and literature searching. Physics/Mathematics backoround and accredited library school degree recuired Recent graduates will be considered. Salary range $\$ 8,400-\$ 12,000$. Please send resume to Mr. L. E. Thomas, Assistant University Librarian for Collections Siman Fraser University, Burnaby, British Columbia Canada.

HUMANITIES LIBRAR|AN. Subject specialist in new li brary building to maintain liaison with faculty and students in subjects of special competence: to participate in collection development; to develop innovative meth ods of library instruction. Recuirements: Graduate degree in library science from ALA accredited school second master's degree, or beyond, in area of humanities, 3 or more years experience in academic library; training in systems analysis will be a plus. Minimum salary: $\$ 10,200$ for 9 months (optional summer work); higher salary dependent upon training and experience. Full mem ber of faculty. Write: Harold E. Helmrich Chief Librarian. Maltby Library, Slippery Rock State College, Slippery Rock, Pa. 16057.

FINE ARTS LIBRARIAN to head new Fine Arts Library. MLS plus minimum two vears' professional experience in fine arts/architecture library: preference also for MA in fine arts or architecture. Instruetor rank or title, onemonth vacation retirement and insurance fringe benefits. Salary $\$, 000$ up, depending upon qualifications. An equal opportunity employer. Send resume to: Kenneth G. Peterson, Associate Librarian, University of Virginia, Charlottesville, Virginia 22901.

8|BLIOGRAPHER, required for collection building in the Humanities. Qualifications should include: library degree, advanced degree in a humanities subject together with some relevant experience. Academic salary (starting range between $\$ 9,405-\$ 11,431)$, usual fringe benefits, TIAA, etc. Appy to: Librarian, Rutgers University Libraries, New Brunswick, N.J. 08901.

Multiple

BIBLIOGRAPHERS: (I) for Romance Languages and Literature (especially French). Broad knowledge of the general subject area, its bibliographic tools, current publishers' output, bibliographic search procedures, and reasonable fluency in trench are required. In-depth knowledge of a particular aspect of the subject, knowledge of out-of-print material and antiquarian dealers, and "luency in other languages will be helpful. (2) for Religion and Philosophy Broad knowledge of the general subject area its bibliographic tools, current publishers subject area, its bibliographic tools, current Publishers
outout and bibliographic search procedures is required. In-depth knowledge or a parficular aspect of the subject. knowledge of out-of-print material and antiquarian deaers and some related language fluency would be helpful (3) for History. Broad knowledge of the general subject area (North American and British history and history of Western Europel, its bibliographic tools, current publishers' output and bibliographic search procedures is required. In-depth knowledge of a particular aspect of the subject, knowledge of out-of-print material and antiquarian dealers and some related language fluency would be hepfut Salary for reach position is $\$ 9,000$ Send resume to R. Max Willocks, Assistant Director of Libraries, 208 Carnegie, Syracuse University, Syracuse, New York 13210.

\section{ERSCO SURSCRIPTION SERVICES}

\section{the world with all known titles. \\ Serial subscription service without equal-regional offices provide personal service. Try us.}

Serving all types of libraries all over

Do you have our Librarian's Handbook? Send $\$ 2.50$ today, and receive this information-packed guide to over 50,000 titles.

To discuss your needs and our services, call us collect.

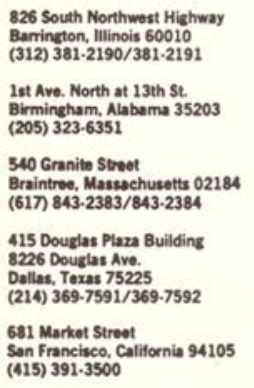

Room 245

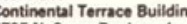
Con $\mathrm{N}$. Speer Boulevard (303) 433.3235

P. O. Box 92901 Los Angeles, California 90009 (213) 772.2381

512 Nicollet Building Minneapolis, Minnesota 55402 (612) 333.5081

EBSCO Building Red Bank, Now Jersey 07701 Red Bank, Now 7 J

5265 Port Royal Road Springfield. Virzinia 22151

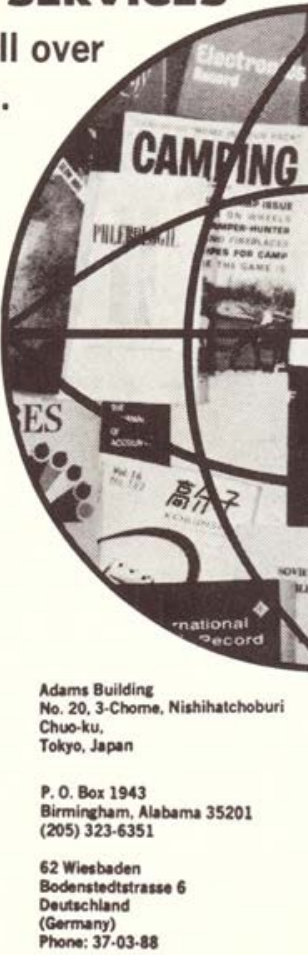

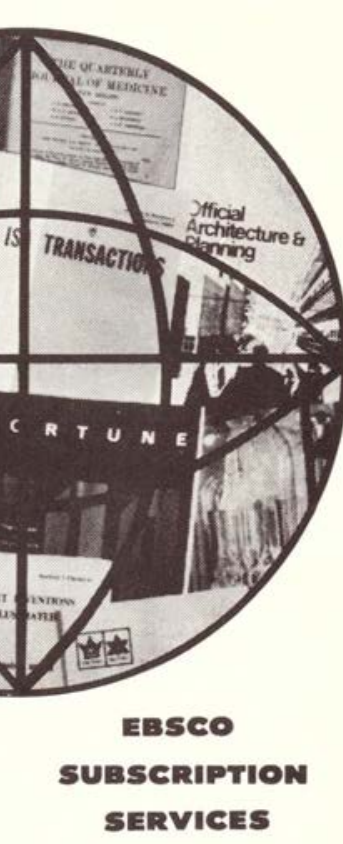

division of

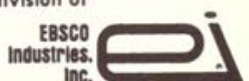




\section{SCIENCE CITATION INDEX ${ }^{\circledR}$}

\section{the reference that sheds}

a whole new light

on literature searching...

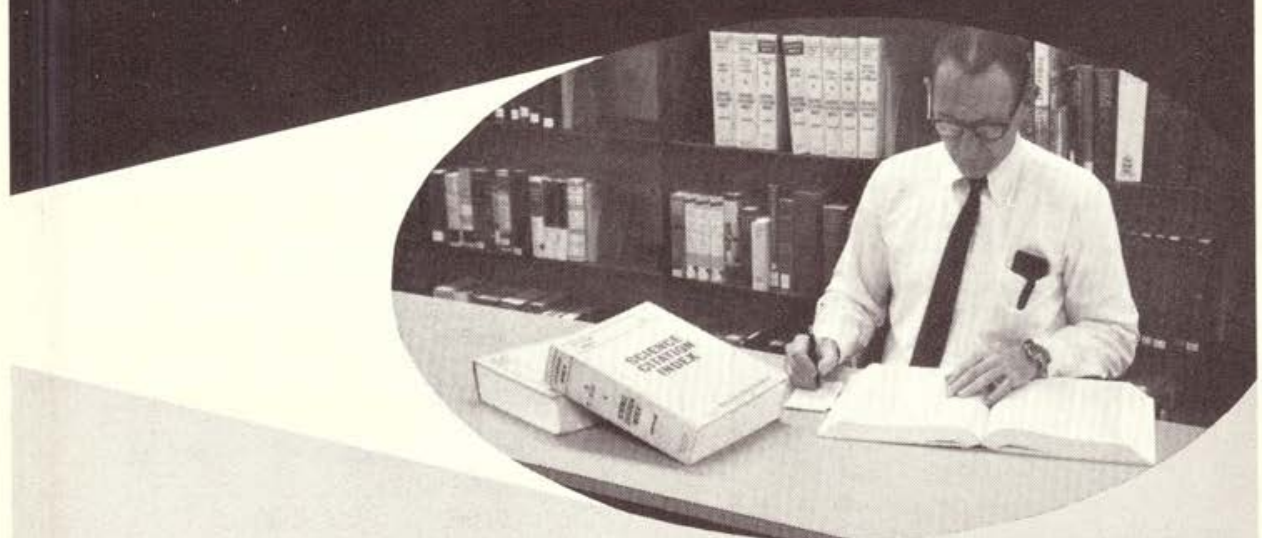

\section{first place to look... for anything}

Science Citation Index - the uniquely effective search tool that organizes the world's current scientific and technical journal literature by the author's own reference citations retrieves more pertinent articles on almost any given subject, faster, than any other reference of any kind.

So it's the first place to look when you want to search the journal literature. For maximum certainty of finding what you're after. For speed and ease of finding it, too.

$\mathrm{SCI}{ }^{\circ}$ is based on the fact that one of the best guides to the subject matter of a scientific article is its bibliography - the people and articles the author himself cited to support his own work. It's called "citation indexing". And study after study has shown this method of organizing the journal literature more effective than conventional indexing systems.

What's more, the Science Citation Index is completely multi-disciplinary - covering every article in every issue of more than 2,400 scientific journals from all over the world. So you need only look in this one, instead of a number of different references.

The next time you need to know what's been published in any specific area of science and technology, turn first to the Science Citation Index. Chances are you'll turn to it first (and last) each time after that. For more on what the Science Citation Index can do for you, send for our free brochure.

Institute for Scientific Information

Dept. 12-299, 325 Chestnut St., Phila., Pa. 19106, (215) 923-3300 
The myopic libra ran who is grits willing to let other people work for legislation, funds, standards, technical and professional improvements from which he benefits, showing no interest in any but his own concern, is getting a frees ride.

GRACE T. STEVENSON

- Federal Legislation

- Guidelines for Academic Libraries

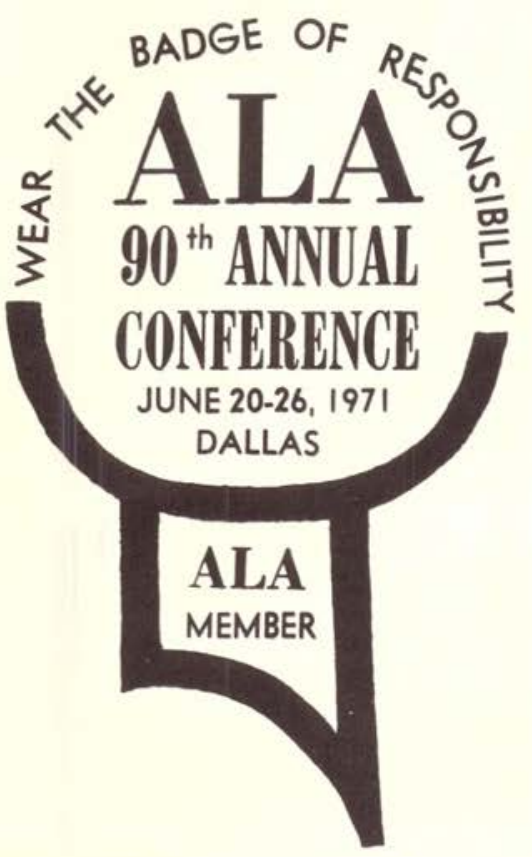

- Academic Status

- A Core Collection for College Libraries

- University Extension Activity

These are only a few areas in which AC RL is involved. Are you involved? ASSOCIATION OF COLLEGE AND RESEARCH LIBRARIES

197 
The name of Frances Neel Cheney is a distinguished one in contemporary American librarianship. Member of the Reference and Subscription Books Review Committee of $A L A$, writer

of a monthly column on current reference books for Wilson Library Bulletin, professor at The Peabody

School of Library Science, she is supremely well qualified to write this book.

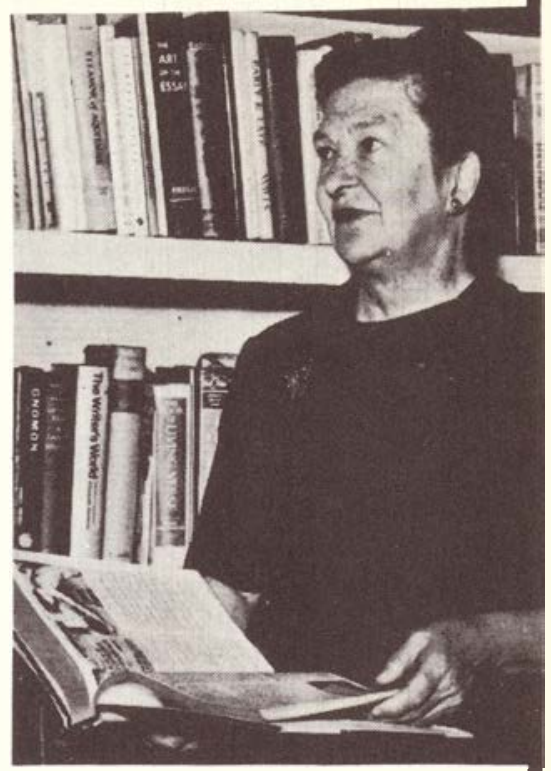

\section{FUNDAMENTAL REFERENCE SOURCES}

\section{FRANCES NEEL CHENEY}

FUNDAMENTAL REFERENCE SOURCES provides an introduction to selected sources of bibliographical, biographical, linguistic, statistical, and geographical information, and offers detailed suggestions for effective use of these sources in selection, acquisition, and cataloging of library collections.

As a textbook in library school courses, or in day-to-day use by librarians, FUNDAMENTAL REFERENCE SOURCES is an indispensable handbook, in the tradition of Shores' Basic Reference Sources-now out of print-and of Winchell's Guide to Reference Books.

ISBN 0-8389-0081-X (1971)

\section{AMERICAN LIBRARY ASSOCIATION}

50 East Huron Street, Chicago, Illinois 60611 


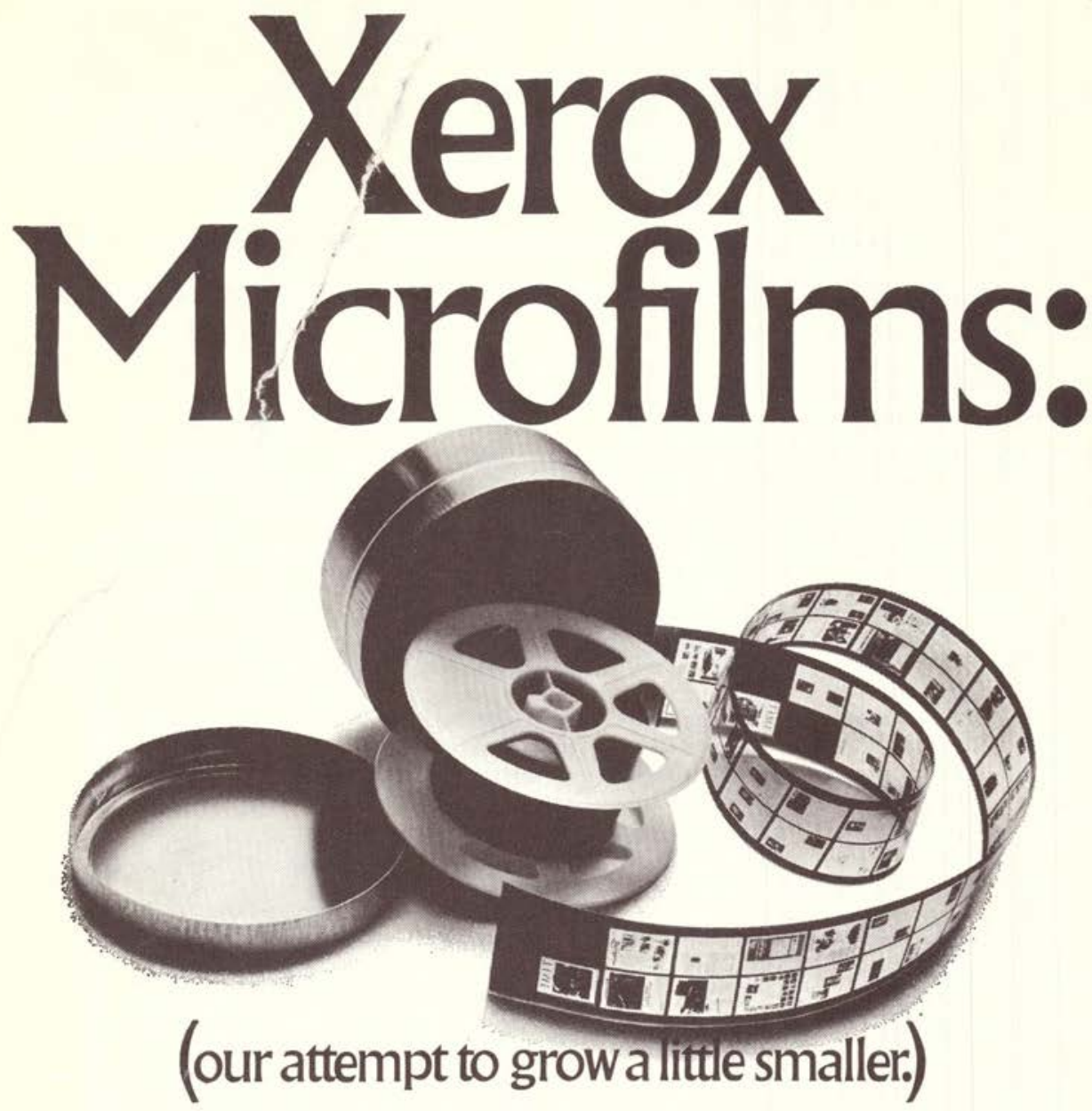

We've grown famous with copiers. Scientific with computers. And quite big in the whole area of information management.

Now we'd like to grow in another direction with Xerox microfilms.

And since we have quite a reputation to uphold, you can be sure we're offering more than a copy.

We think our microfilms are a little better, more consistent, and a lot easier to use (whatever equipment and chemicals you prefer). And we'll gladly provide free samples to prove it. We have Negative Antihalation Undercoated $\mathrm{XMH}(16,35,105 \mathrm{~mm})$ for planetary cameras; Negative Dyeback XMD $(16 \mathrm{~mm})$ for flow-type cameras; and Positive XMP (16 and $35 \mathrm{~mm}$ ) for contact film printers.

One other thing: To simplify ordering, speed deliveries, and reduce your inventories, you can order it direct from your local Xerox Sales Office for fast shipment from our Regional Supply Centers. Consult your telephone directory.

That's another original from Xerox Corporation, Business Products Group, Dept. HR, Rochester, New York 14603.

\section{XEROX.}




\section{NATIONAL FAEULTY DIRECTORY-1971 READY NOW!}

\section{HERE'S WHAT REVIEWERS HAVE SAID:}

HIGHER EDUCATION BOOK REVIEW "The National Faculty Directory is a thorough and comprehensive volume and an invaluable source material for personnel in the academic community and otherwise. A 'must' reference aid in any admınistrative-academic office." (July 1, 1970)

AMERICAN LIBRARIES "Right straight out of a data bank in crisp. easy-to-read, five column, $8 \frac{1}{2}$ by 11 inch pages, this is a must for every library reference crew." (July-August, 1970)

SCIENCE BOOKS: A QUARTERLY REVIEW "This should prove to be a widely used reference in colleges, universities, public libraries, educational and professional organizations, etc.... Highly recommended." (September, 1970)

\section{- AND THE FIRST EDITION WAS INCLUDEO IN COLLEGE AND RESEARCH LIBRARIES "SELECTED REFERENCE BOOKS OF 1969-70" (JANUARY, 1971)}

A REFERENCE WORK OF PROVEN USEFULNESS-The comments above concerning the usefulness of the first edition of NFD will be even more true of the Second Edition, which covers scores of additional schools (including selected Canadian colleges) and nearly 60.000 more faculty members than the highly praised 1970 edition

1971 EDITION EXTENSIVELY REVISED-Arranged alphabefically by faculty names, the listings in the 1971 NFO have been carefully confirmed of revised on the basis of recent catalogs and faculty lists. Infor. mation furnished on each of the nearly 380.000 members of teaching faculties and major administrators includes the individual's name. instutution name. departmental designation. street address if necessary. and city. state. and zip. There is. for the first time. a list of the approximately 2.800 schools covered.

COVERAGE INCREASED IN 1971 --Over ninety-five percent of teaching faculty members and major administrators in the United States can be located with the aid of NFO The next time you need to find out "who's where" in the academic world, you can confidently turn to The National Faculty Directory for current. complete information

\begin{tabular}{|c|c|}
\hline \multicolumn{2}{|c|}{ SAMPLE } \\
\hline $\begin{array}{l}\text { LEESE Chester E, Dept of Biol, Mariorie } \\
\text { Webster Jf Coll, Kalmio Rd \& 17th St. } \\
\text { Wash D C } 20012\end{array}$ & $\begin{array}{l}\text { LEFEAVERS Perry L, Dept of Phys Ed, } \\
\text { Woke Forest Univ, Winston - Solem N C } \\
27109\end{array}$ \\
\hline $\begin{array}{l}\text { LEESE John W, Dept of Phys Ed, Triton } \\
\text { Coll, } 20005 \text { th Ave, River Grove Ill }\end{array}$ & $\begin{array}{l}\text { LEFEBER Louis, Dept of Econ, Brandeis } \\
\text { Univ, Waltham Mass } 02154\end{array}$ \\
\hline 60171 & LEFEBRE Charleene C, Dept of Sociol. \\
\hline $\begin{array}{l}\text { LEESE Philip, Dept of Engrg Tech, } \\
\text { Asheville Buncombe Tech Inst, } 340\end{array}$ & $\begin{array}{l}\text { Lower Columbia Coll, Longview Wosh } \\
98632\end{array}$ \\
\hline $\begin{array}{l}\text { Victoria Rd, Asheyille N C } 28801 \\
\text { LEESEBERG Donald G, Dean of Bus, } \\
\text { Wis St Univ, Whitewater Wis } 53190\end{array}$ & $\begin{array}{l}\text { LEFEBRE Charles I, Dept of English, } \\
\text { Lower Columbia Coll, Longview Wash } \\
98632\end{array}$ \\
\hline $\begin{array}{l}\text { LEESEBERG Keith R, Dept of Bus } \\
\text { Admin, Florissant Valley Coll, St Louis } \\
\text { Mo } 63135\end{array}$ & $\begin{array}{l}\text { LEFEBRE Vernon G, Dept of Physics, } \\
\text { NM Tech, Socorro N Mex } 87801 \\
\text { LEFEBRE - MUNOZ Rohero. }\end{array}$ \\
\hline LEESEBERG Martin W, Dept of Relig, & $\begin{array}{l}\text { LEFEBRE - MUNOZ Roberto, Dept of } \\
\text { Agri Ed, Univ of PR, Mayaguez P R }\end{array}$ \\
\hline
\end{tabular}

THE NATIONAL FACULTY DIRECTORY-1971 Available Immediately. .. Two Volumes ... Clothbound ... 568.50 